NASA Technical Memorandum 106879

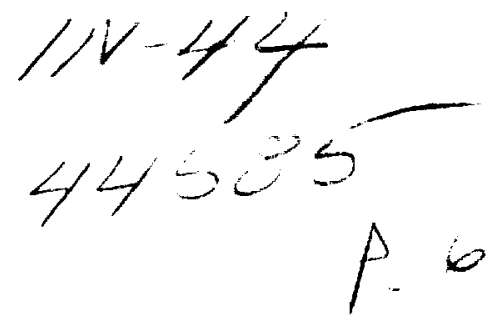

\title{
Use of Advanced Solar Cells for Commercial Communication Satellites
}

Sheila G. Bailey

National Aeronautics and Space Administration

Lewis Research Center

Cleveland, Ohio

and

Geoffrey A. Landis

NYMA Inc.

Engineering Services Division

Brook Park, Ohio

Prepared for the

First World Conference on Photovoltaic Energy Conversion cosponsored by the IEEE, PVSEC-JAPAN, and PVSEC-EUROPE Waikoloa, Hawaii, December 5-9, 1994

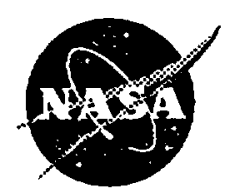

National Aeronautics and Space Administration

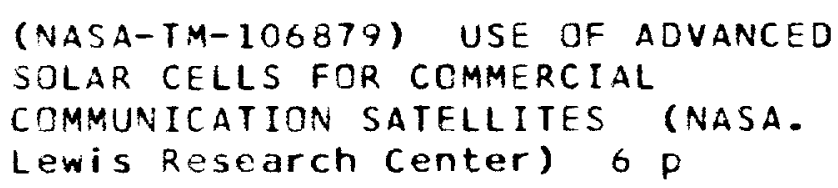

Unclas 


\title{
USE OF ADVANCED SOLAR CELLS FOR COMMERCIAL COMMUNICATION SATELLITES
}

\author{
Sheila G. Bailey \\ NASA Lewis Research Center, Cleveland, $\mathrm{OH} 44135$ \\ Geoffrey A. Landis \\ Nyma, Inc., NASA Lewis Research Center, Cleveland, OH 44135
}

\begin{abstract}
The current generation of communications satellites are located primarily in geosynchronous Earth orbit (GEO). Over the next decade, however, a new generation of communications satellites will be built and launched, designed to provide a world-wide interconnection of portable telephones. For this mission, the satellites must be positioned in lower polar and near-polar orbits. To provide complete coverage, large numbers of satellites will be required. Because the required number of satellites decreases as the orbital altitude is increased, fewer satellites would be required if the orbit chosen were raised from low to intermediate orbit. However, in intermediate orbits, satellites encounter significant radiation due to trapped electrons and protons. Radiation tolerant solar cells may be necessary to make such satellites feasible. We analyze the amount of radiation encountered in low and intermediate polar orbits at altitudes of interest to next-generation communication satellites, calculate the expected degradation for silicon, GaAs, and InP solar cells, and show that the lifetimes can be significantly increased by use of advanced solar cells.
\end{abstract}

\section{WTRODUCTION}

The current generation of communications satellites are located primarily in geosynchronous Earth orbit (GEO). Over the next decade, however, a new generation of communications satellites will be built and launched. A recent study indicated that there will be a market for as many as four of these worldwide communications satellites systems, and that these will produce a revenue of $\$ 9$ billion per year [1].

These next-generation communications satellites will be designed to provide a world-wide interconnection of portable telephones. For this mission, to allow the use of low-power hand-held telephones and very small aperture antennas, the satellites must be positioned in lower polar- and nearpolar orbits. To provide complete coverage, large numbers of satellites will be required; as few as 66 satellites for the Iridium system, or as many as $\mathbf{9 0 0}$ satellites for the Teledesic system.

The required number decreases significantly as the orbital ahitude is increased. Far fewer satellites are required if the orbit chosen is raised from Low
Earth Orbit (LEO) to intermediate Earth orbit. By doing this, however, the radiation environment of the satellite is significantly increased, resulting in decreased lifetime. I is the purpose of this paper to demonstrate the savings that can be achieved by use of higher orbits and to show that, by using improved, radiation-tolerant solar cells [2], the lifetimes can be increased substantially, allowing these higher orbits to be used.

\section{REQURREMENTS}

The number of satelites required as a function of altitude can be calculated if the view angle for each satellite and the constellation geometry are known. We will assume here that the constellation consists of satellites in circular polar (or near-polar) orbits. This is not necessarily the optimum constellation for all purposes, however, it is similar to the constellations proposed for next-generation systems, and has the advantage of being easily calculable. For other constellation geometries, the number of satellites required to provide complete coverage differs by a constant muliplicative factor.

Satellite view angle accounts for the fact that a ground station cannot communicate with a satellite all the way down to the horizon due to horizon clutter, mountains, buildings, etc. Here we assume a view angle (measured from the zenith) $\alpha=85^{\circ}$; that is, a satellite is in view of a ground station if it is $5^{\circ}$ or higher above the horizon. For view angle $\alpha$ and an orbital allitude (measured above the surface) of $h$, the number of degrees that a given satellite can be viewed from is:

$$
D=2 \alpha-2 \sin ^{-1}[\sin \alpha /(1+h / R)]
$$

where $R$ is the radius of the Earth. Complete, uninterrupted coverage of the Earth can be achieved using a constellation of polar (or near-polar) orbit satellites if there are

$$
n_{\text {sat }}=180 \sqrt{2}\left[1 / \alpha-\sin ^{-1}[\sin \alpha /(1+h / R)]\right]
$$

satellites in each orbital plane, and

$$
n_{\text {planes }}=180 / \sqrt{2}\left[1 / \alpha-\sin ^{-1}[\sin \alpha /(1+h / R)]\right]
$$
orbital planes.

For an altitude of $780 \mathrm{~km}$, this calculation shows that 11.24 satellites are required per orbital plane, and 5.7 orbital planes will be needed. (Clearty, for actual 
systems integral numbers are required.) In comparison, the Iridium satellite system, with a proposed aktitude of 780 kilometers, and an inclination of $86^{\circ}$, uses 11 satellites per orbital plane, and 6 orbital planes. The agreement between calculated and actual number of satellites is good.

If we neglect the fact that the number of satellites per orbital plane, and the number of orbital planes, must be an integer, the total number of satelites to provide complete coverage of the Earth's surface can be approximated as:

$$
N=\pi^{2}\left[1 / \alpha-360 / \pi \sin ^{-1}[\sin \alpha /(1+h / R)]\right]^{2}
$$

This is shown in figure 1 for the case of a satellite view angle of $85^{\circ}$. For example, for low Earth orbit (LEO) at an orbital altitude of $780 \mathrm{~km}, 66$ satellites are required to provide complete global coverage. By changing to an intermediate orbit above $3000 \mathrm{~km}$, on the other hand, three orbital planes with six satellites per plane are sufficient. This reduces the required number of satellites from 66 to 18.

In intermediate orbits, satelites encounter significant radiation due to trapped electrons and protons in the Earth's Van Allen belts. (In fact, at the ahtitudes of interest, the dominant radiation is from trapoed protons). In Figure 2 the annual equivalent 1MoV electron fluence from trapped protons (Pmax, Voc) are shown for a silicon solar cell with infinite back shiolding in polar orbit as a function of shield thickness and altitude $[3,4]$. High radiation levels will result in degradation of both the on-board electronics and of the spececraft solar arrays. While the electronics can in principle, be shielded from direct exposure, and radiation tolerance components can be chosen, the solar amay must necessarily be exposed to the environment. The lifetime of satellites in the intermediate Earth orbits discussed is thus expected to be limited by the radiation damage of the solar arrays.

Figure 3 compares the total radiation fluence over the five-year nominal lifetime of the satellite for the orbits of interest, comparing 700 and $3200 \mathrm{~km}$ polar orbits wh equatorial LEO and geosynchronous orbit. These fluences are calculated in terms of equivalent electron exposure seen by a $200 \mu \mathrm{m}$ silicon solar cell with a $125 \mathrm{\mu m}$ coverglass and a flexible substrate. In $3200 \mathrm{~km}$ orbit, the satellite encounters radiation levels neary three orders of magnitude more than those encountered in the $700 \mathrm{~km}$ orbit.

Figure 4 shows the calculated loss of array power tue to radiation damage in the $3200 \mathrm{~km}$ polar orbit. Details on the calculation procedure are discussed in roference [5]. For this graph, a front coverglass thickness of $125 \mathrm{\mu m}$ (5 mils) was assumod. Silicon cells with a lightweight flexible array structure that provides 50 microns of backside shielding degrade to almost zero performance in the first month of coration. This is clearly not a usable array structure. A conventional rigid array, with effectively infinite backside shielding, decreases the degradation, but the silicon cell still loses power at an unacceptably high rate.

In contrast, InP solar cells have considerably higher radiation tolerance [6]. Using the same array structure and coverglass thickness as the silicon cell, an array using InP solar cells will lose onty $20 \%$ of initial power during the first year of operation. Increasing the coverglass thickness to provide more shielding will result in lower levels of degradation, and allow the array to provide acceptable power levels for the full five-year satellite lifetime, even in the highradiation orbit.

While use of the higher orbits will incur higher launch costs per satellite, the decreased number of satellites more than compensates for the increased launch cost. Further, in most communication satellite systems the launch cost comprises typically less than a third of the total satellite cost; in some cases, considerably less than a third. (For example, for the Firesat LEO satellite analyzed by Wong [7], only $16 \%$ of the satellite cost (not including engineering and development) were the launch costs. By using advanced cells, the overall cost is decreased nearty proportionately to the decrease in number of satellites required.

\section{CONCLUSIONS}

Use of intermediate Earth orbit for next-generation communications satellites could reduce the number of satellites required by a factor of four. Calculations show that conventional silicon solar cells degrade too rapidly in the radiation environment to achieve the required 5 year lifetime in intermediate orbit. InP solar cells could allow the array to function for the full satellite lifetime. Similar conclusions were reached by Inmarsat. According to deSelding [8], the price of the Inmarsat-P wordwide telephone satellite constellation reduces from 3 billion dollars to 2 billion, and the number of satellites is reduced from 54 to 12-15, if intermediate orbit of 10,300 km is chosen instead of LEO. By using advanced solar cells, the functionality of advanced communication satellite systems could be substantially increased.

\section{REFERENCES}

[1] "Study Claims LEO Market Can Support Four Systems," Space News, June 13-19 (1994).

[2] G.A. Landis, S.G. Bailey and M. Piszczor, "Recent Advances in Solar Cell Technology, 33rd ANA Aerospace Sciences Meeting and Exhibit, Reno NV, 9-12 January 1995.

[3] H.Y. Tada, J.R. Carter, Jr., B.E. Anspaugh, and R.G. Downing, Solar Coll Radiation Handbook, 3ro od., JPL Publication 82-69, Nov. 1, 1982.

[4] B.E. Anspaugh, Solar Coll Radiation Handbook Addendum 1: 1982-1988.

[5] S.G. Bailey, I. Weinberg and D.J. Flood, Advanced Power Systems for Éos", Proceedings of the 26th Intersociety Energy Conversion Engineering Conference, Vol. 2, 250-255, (1991).

[6] 1. Woinberg, "InP Solar Cells for Use in Space," Solar Cells, 29(2-3), 225-244 (1990).

i7] R. Wong, "Cost Modeling," chapter 20, Spece Mission Analysis and Design, 2nd od., W.J. Larson and J.R. Wertz, eds., Microcosm, Torrance, CA, 737. (1992).

[8] P. deSelding, "Inmarsat Drops LEO Concept," Space Nows, and "Inmarsat Takes First Step to Privatization," Space News, May 16-22, 1 (1994). 


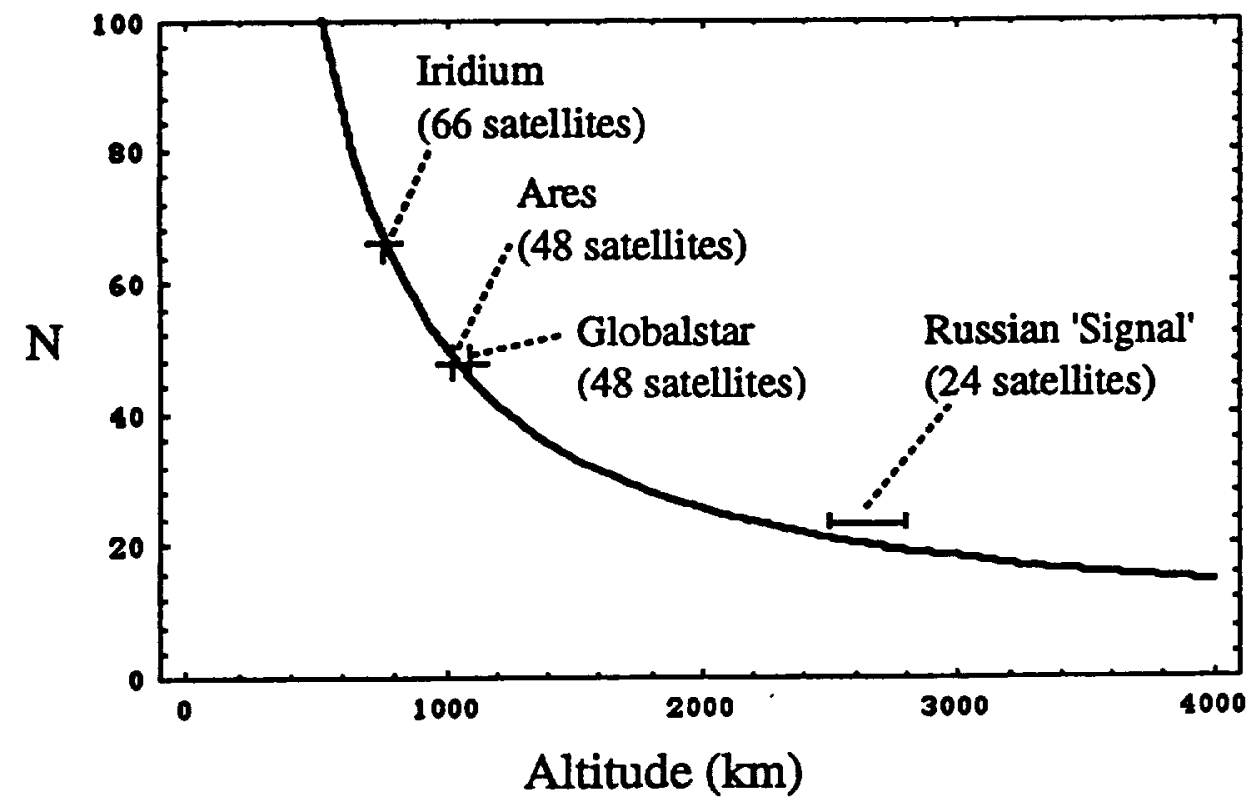

Figure 1. Number of satellites in circular polar (or near-polar) orbit required to provide global coverage as a function of altitude (assuming a horizon angle of $5^{\circ}$ )

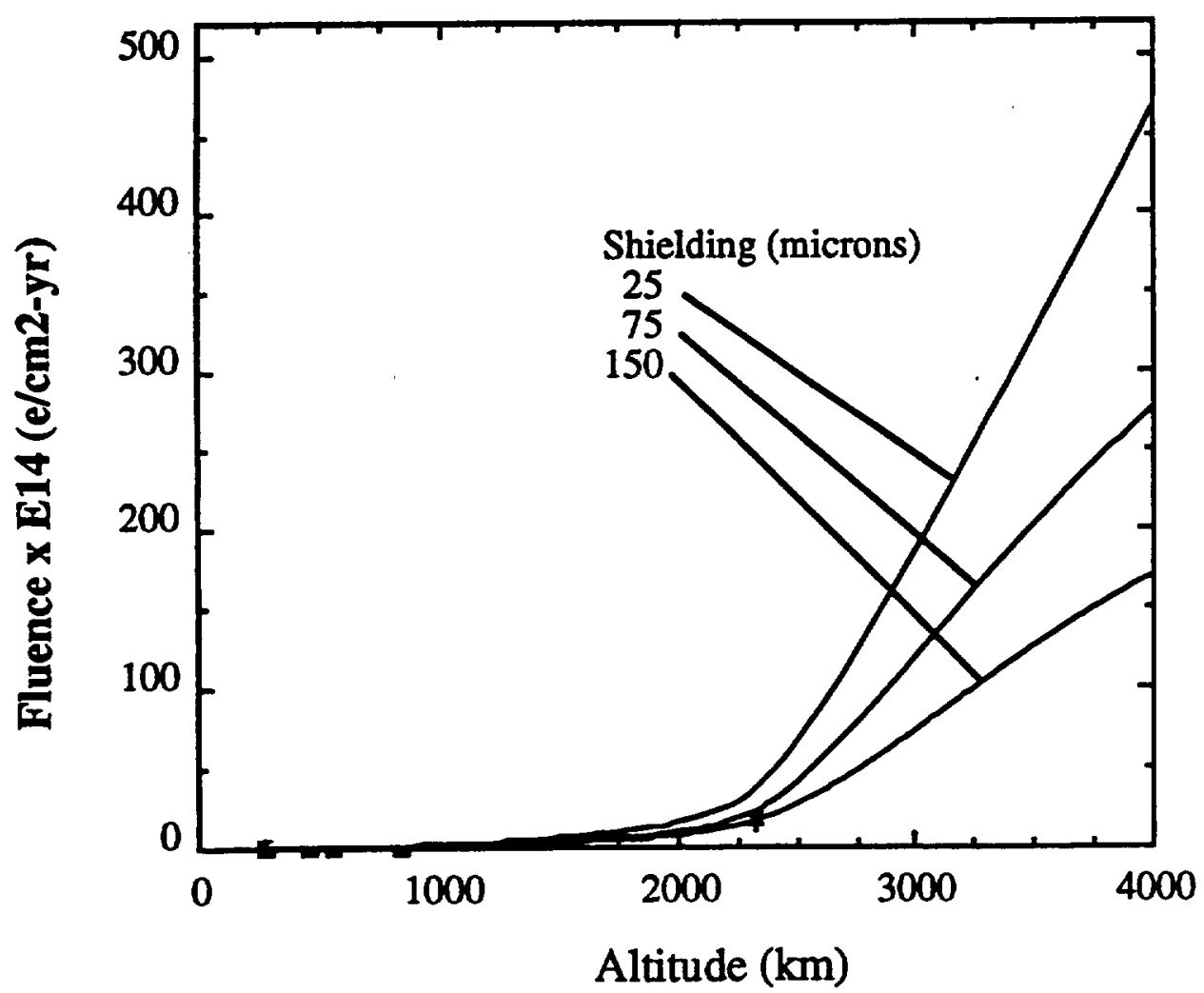

Figure 2. Annual Equivalent $1 \mathrm{MeV}$ Electron Fluence from Trapped Protons at $100^{\circ}$ Inclination 


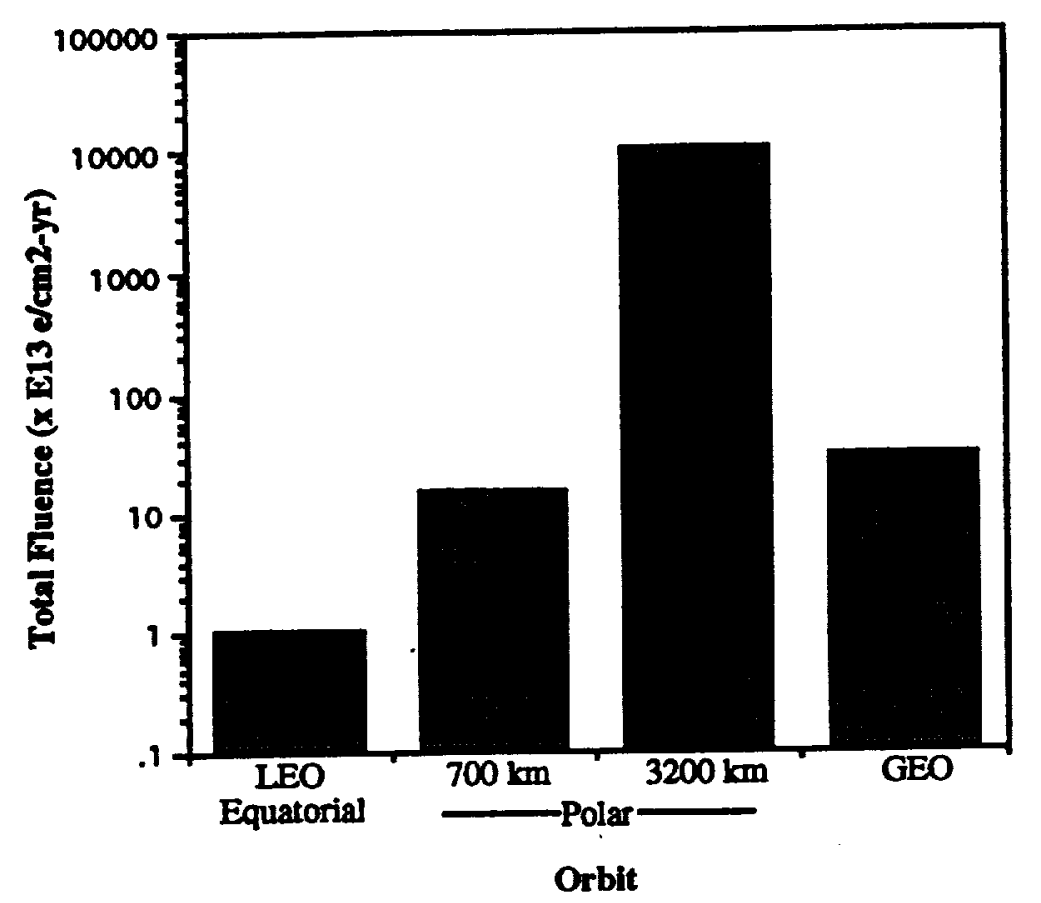

Figure 3. Radiation dose at the end of the five-year nominal lifetime as a function of orbit.

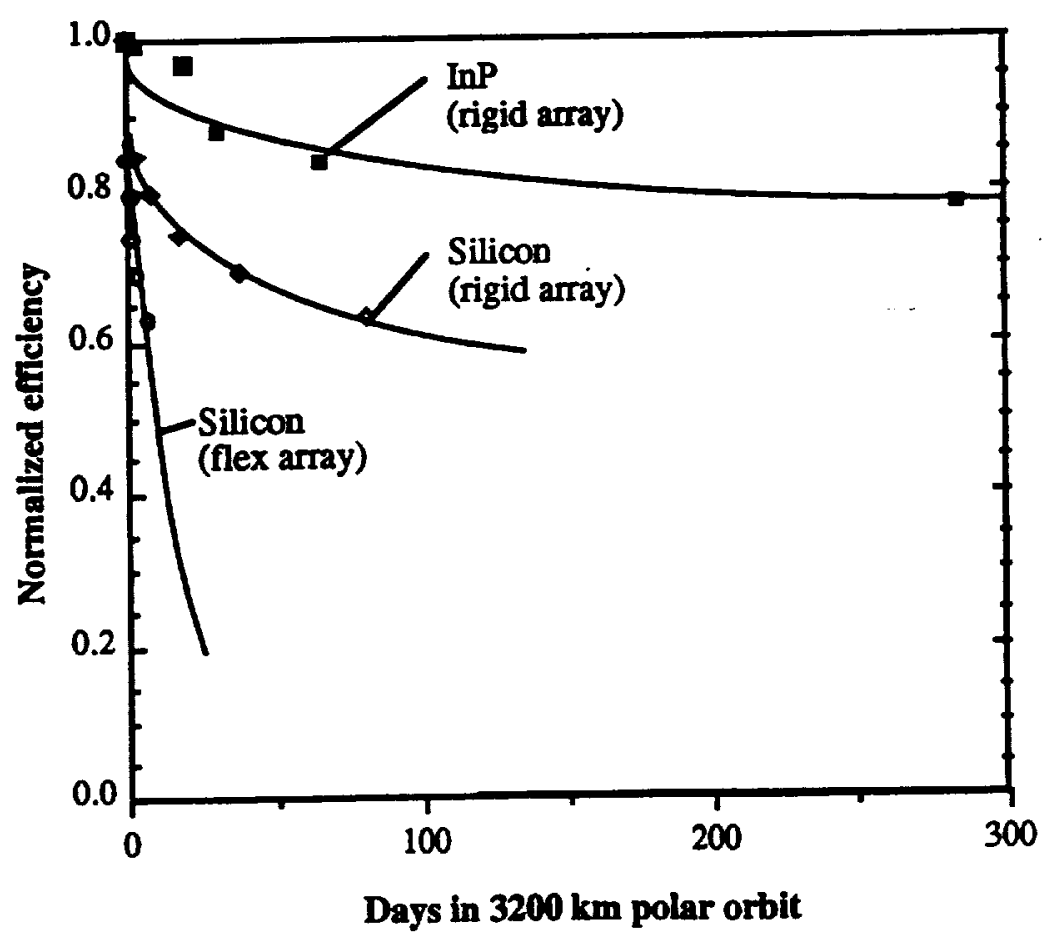

Figure 4. Decrease in efficiency for silicon and InP solar cells in $3200 \mathrm{~km}$ polar orbit. 

Public reporting burden for this collection of information is estimated to average 1 hout per response, including the time for reviewing instructions, searching existing data sources, Public reporting burtaining the data needed, and completing and reviewing the collection of inlormation. Send comments regarding this burden estimate of any other aspect of this gatherng an interions Davis Highway, Suite 1204. Aftington. VA 22202-4302, and to the Office of Management and Budget, Papenwork Reduction Projact (0704-0188). Washington. DC 20503.

\begin{tabular}{l|l|l|}
\hline 1. AGENCY USE ONLY (Leave blank) & 2. REPORT DATE & 3. REPORT TYPE AND DATES COVERED
\end{tabular}

\begin{tabular}{|l|l|r|}
\hline 1. AGENCY USE ONLY (Leave blank) & $\begin{array}{c}\text { 2. REPORT DATE } \\
\text { March } 1995\end{array}$ & $\begin{array}{r}\text { 3. REPORT TYPE AND DATES COVERED } \\
\text { Technical Memorandum }\end{array}$
\end{tabular}

4. TITLE AND SUBTITLE 5. FUNDING NUMBERS

Use of Advanced Solar Cells for Commercial Communication Satellites

6. AUTHOR(S)
Sheila G. Bailey and Geoffrey A. Landis

WU-233-01-0A

7. PERForming ORgANIRATION NAME(S) AND ADDRESS(ES)

8. PERForming ORganization REPORT NUMBER

National Aeronautics and Space Administration

Lewis Research Center

Cleveland, Ohio 44135-3191

E-9515

9. SPONSORING/MONITORING AGENCY NAME(S) AND ADDRESS(ES)

National Aeronautics and Space Administration

Washington, D.C. 20546-0001

NASA TM-106879

11. SUPPLEMENTARY NOTES

Prepared for the First World Conference on Photovoltaic Energy Conversion cosponsored by the IEEE, PVSEC-JAPAN, and PVSECEUROPE, Waikoloa, Hawaii, December, 5-9, 1994. Sheila G. Bailey, NASA Lewis Research Center and Geoffrey A. Landis, NYMA, Inc., Engineering Services Division, 2001 Aerospace Parkway, Brook Park, Ohio 44142 (work funded by NASA contract NAS3-25266 with Sverdup Technology Inc.). Responsible person, Sheila G. Bailey, organization code 5410, (216) 433-2228.

12a. DISTRIBUTIONAVAILABILTTY STATEMENT 12b. DISTRIBUTION CODE

Unclassified - Unlimited

Subject Category 44

This publication is available from the NASA Center for Aerospace Information, (301) 621-0390.

13. ABSTRACT (Maximum 200 words)

The current generation of communications satellites are located primarily in geosynchronous Earth orbit (GEO). Over the next decade, however, a new generation of communications satellites will be built and launched, designed to provide a world-wide interconnection of portable telephones. For this mission, the satellites must be positioned in lower polar and near-polar orbits. To provide complete coverage, large numbers of satellites will be required. Because the required number of satellites decreases as the orbital altitude is increased, fewer satellites would be required if the orbit chosen were raised from low to intermediate orbit. However, in intermediate orbits, satellites encounter significant radiation due to trapped electrons and protons. Radiation tolerant solar cells may be necessary to make such satellites feasible. We analyze the amount of radiation encountered in low and intermediate polar orbits at altitudes of interest to next-genertation communication satellites, calculate the expected degradation for silicon, GaAs, and InP solar cells, and show that the lifetimes can be significantly increased by use of advanced solar cells.

\begin{tabular}{|c|c|c|}
\hline $\begin{array}{l}\text { 14. SUBJECT TERMS } \\
\text { Photovoltaics; Communications; Satellites }\end{array}$ & $\begin{array}{c}\text { 19. SECURITY CLASSIFICATION } \\
\text { OF ABSTRACT } \\
\text { Unclassified }\end{array}$ \\
\hline $\begin{array}{c}\text { 17. SECURTY CLASSIFICATION } \\
\text { OF REPORT } \\
\text { Unclassified }\end{array}$ & $\begin{array}{c}\text { 18. SECURTY CLASSIFICATION } \\
\text { OF THIS PAGE } \\
\text { Unclassified }\end{array}$ &
\end{tabular}

